\title{
Differential Expression of Motivational Stimulus Properties by Dopamine in Nucleus Accumbens Shell versus Core and Prefrontal Cortex
}

\author{
Valentina Bassareo, Maria Antonietta De Luca, and Gaetano Di Chiara \\ Department of Toxicology and Consiglio Nazionale delle Ricerche, Center for Neuropharmacology, University of Cagliari, \\ 09124 Cagliari, Italy
}

The response of extracellular dopamine (DA) and its relationship to motivational valence (positive or negative) and novelty of motivational stimuli was investigated by brain microdialysis in the nucleus accumbens (NAc) shell and core and prefrontal cortex (PFCX) of rats. Stimuli were elicited by intraoral infusion of $20 \%$ sucrose, sucrose plus chocolate, quinine, and $\mathrm{NaCl}$ solutions, feeding of a palatable food (Fonzies), or smelling of a predator (red fox) urine. Sucrose elicited appetitive reactions and increased DA in the PFCX but not in the NAc shell. An unfamiliar appetitive taste such as that of sweet chocolate and Fonzies, increased DA in all three areas. Habituation of the stimulatory DA response to intraoral chocolate or to Fonzies feeding was observed in the NAc shell after a single preexposure to the same taste or food; no habituation was ob- served in the NAc core nor in the PFCX. Aversive taste stimuli (quinine, saturated $\mathrm{NaCl}$ solutions) rapidly increased DA in the PFCX and in the NAc core, and this response did not undergo one-trial habituation. In the NAc shell, instead, no effect (10 min exposure) or a delayed, transitory increase of DA (5 min exposure) sensitive to one-trial habituation was obtained in response to the aversive taste (quinine and saturated $\mathrm{NaCl}$ ) or olfactory (red fox urine) stimuli. These observations indicate that DA responsiveness is an integrated function of the motivational valence and novelty of stimuli in the NAc shell and an expression of generic motivational value in the NAc core and PFCX.

Key words: aversion; dopamine; feeding; microdialysis; motivation; nucleus accumbens; predator odor; prefrontal cortex; reward
Although brain dopamine (DA) is traditionally viewed as involved in the acquisition and expression of motivation and reinforcement, the motivational response properties of the different subpopulations of DA neurons projecting to the various DA terminal areas [e.g., prefrontal cortex (PFCX), nucleus accumbens (NAc), shell and core] is unclear and is the subject of much debate (Phillips et al., 1991; Di Chiara, 1995; Westerink, 1995; Salamone, 1996; Berridge and Robinson, 1998; Schultz, 1998; Redgrave et al., 1999; Horvitz, 2000). Extracellular recording of presumed DA neurons in the monkey showed that DA neurons phasically respond in a uniform manner throughout the mesencephalon to the unpredicted occurrence or omission of primary and secondary appetitive stimuli (Schultz et al., 1993, 1997) but are relatively unresponsive to aversive stimuli (Mirenowicz and Schultz, 1996). These observations contrast with those of other studies showing that primary aversive stimuli stimulate the firing of DA units in cats and in rats (Horvitz et al., 1997) and increase extracellular DA in various terminal DA areas (Abercrombie et al., 1989; Imperato et al., 1989; Kalivas and Duffy, 1995; Bassareo et al., 1996). On the other hand, conventional and drug rewards have been reported by various studies to differentially affect extracellular DA in different areas (Di Chiara, 1995; Westerink, 1995; Wilson et al., 1995; Pontieri et al., 1995, 1996; Bassareo and Di Chiara, 1997, 1999a; Tanda et al., 1997).

These discrepancies could be attributable to the difficulties in

\footnotetext{
Received Feb. 4, 2002; revised Feb. 4, 2002; accepted March 15, 2002.

This work was performed with funds from Ministero dell'Università della Ricerca Scientifica e Technologica (40 and 60\%) and from the Center for Neuropharmacology.

Correspondence should be addressed to Prof. Gaetano Di Chiara, Dipartimento di Tossicologia, Via Ospedale 72, 09124 Cagliari, Italy. E-mail: diptoss@tin.it. Copyright (C) 2002 Society for Neuroscience 0270-6474/02/224709-11\$15.00/0
}

comparing the effects of motivational stimuli differing not only for their valence (appetitive versus aversive) but also for their sensory modality (e.g., electric shock versus palatable food; Salamone, 1994; Berridge and Robinson, 1998; Horvitz, 2000). A further problem derives from the difficulty of comparing results obtained with such different techniques as microdialysis and electrophysiology that are likely to estimate different aspects of the function of DA neurons. Thus, whereas microdialysis studies can relate changes in DA function to specific subpopulations of DA neurons by monitoring extracellular DA at terminal DA areas, the electrophysiological studies performed in the monkey have not systematically identified the site of termination of extracellularly recorded DA units (Schultz et al., 1993, 1997). To circumvent the first difficulty, we selected motivational stimuli sharing taste as sensory modality and differing in motivational valence as a result of their different composition (e.g., quinine versus sweet chocolate) or concentration of the same component (e.g., diluted versus concentrated sodium chloride solutions). As to the second problem, we systematically used brain microdialysis with concentric probes in freely moving rats, which allows the estimation of DA transmission in selected terminal areas of behaving rats (Ungersted, 1984; Di Chiara et al., 1996).

In the present study we investigated the response of DA transmission to aversive and appetitive taste stimuli in three DA terminal areas: the NAc shell, the NAc core, and the PFCX. To directly correlate motivational valence with changes in DA transmission, rats were implanted with intraoral cannulas, and the behavior was monitored according to a taste reactivity paradigm after direct intraoral infusion of solutions (Berridge, 2000). To evaluate the role of stimulus modality in the responsiveness of NAc DA, the effect of exposure to a predator odor (red fox 
urine), i.e., to a primary olfactory aversive stimulus, was also studied. Finally, to evaluate the role of stimulus novelty, rats were exposed after $24 \mathrm{hr}$ to the same taste stimulus, and the effects were compared with those obtained in a control group exposed 24 $\mathrm{hr}$ before to the taste of water.

\section{MATERIALS AND METHODS}

Animals. Male Sprague Dawley rats (Charles River, Calco, Italy) weighing 200-250 gm were housed in group of six per cage with standard food (Stefano Morini, San Polo D'Enza, Reggio Emilia, Italy) and water ad libitum, for at least 1 week in the central animal room, under constant temperature $\left(23 \mathrm{C}^{\circ}\right)$, humidity $(60 \%)$, and a $12 \mathrm{hr}$ light/dark cycle (light from 8:00 A.M. to 8:00 P.M.).

Materials. Rats were infused intraorally with water, with a sucrose (SADAM SpA Villasor, Cagliari, Italy) solution (20\%), with $\mathrm{NaCl}$ (Farmitalia Carlo Erba, Milano, Italy) solutions $(0.3 \mathrm{M}$ or saturated solution) and with a solution of chocolate syrup (Yoo-hoo; Yoo-hoo Corporation, Carlstadt, NJ) and tap water 1:1. The chocolate syrup contained: sucrose $40 \%$, corn syrup, water, cocoa, nonfat milk powder, salt, preservative E202, emulsifier E415, and artificial flavor. Bitter solutions were obtained dissolving quinine $\mathrm{HCl}$ in tap water (quinine hydrochloride; Sigma, Milan, Italy).

Fonzies (KP Snack Foods, München, Germany) are a highly palatable food made of corn flour, hydrogenate vegetable fat, cheese powder, and salt. Fonzies contain $8 \%$ protein, $33 \%$ fat, and $53 \%$ carbohydrates for a caloric value of $541 \mathrm{kcal} / 100 \mathrm{gm}$.

Rats of pre-exposed groups were infused with solutions $24 \mathrm{hr}$ before the microdialysis experiment or were presented with Fonzies $2 \mathrm{hr}$ after a first feeding trial during the same microdialysis session. Control rats were infused with water $24 \mathrm{hr}$ before the microdialysis experiment.

Rats were exposed to a predator odor by presenting at a distance of $\sim 5$ $\mathrm{cm}$ and for $5 \mathrm{~min}$ a wad soaked with red fox urine (Red fox P; Timk's, Safariland Hunting Corp., Trappe, MA) placed at the end of a stick.

All animal experiments were conducted in accordance with the statement revised and approved by the Society for Neuroscience in January 1995 and with the guidelines for care and use of experimental animals of the European Economic Commission (EEC Council 86/609; DL: 27.01.1992, $\left.\mathrm{N}^{\circ} 116\right)$.

Probe and oral catheter preparation. Concentric dialysis probes with a dialyzing portion of $2 \mathrm{~mm}$ were prepared with AN69 fibers (Hospal Dasco, Bologna, Italy), according to the method of Di Chiara et al. (1993) as modified by Tanda et al. (1996).

The oral catheter was made of a 22 gauge stainless steel needle and of a polyethylene (PE) tubing (Polyethylene tubing; Portex limited, Hythe, Kent, UK) (inner diameter $0.58 \mathrm{~mm}$, outer diameter $0.96 \mathrm{~mm}$ ). The 22 gauge stainless steel needle was cut on one side (length $2 \mathrm{~cm}$ ), was blunted, and was inserted in the PE tubing that was ending with a perforated circular disk.

Surgery. Rats were anesthetized with $100 \mathrm{mg} / \mathrm{kg}$ intraperitoneally. Ketamine HCl (Ketavet; Farmaceutici Gellini, Latina, Italy) and placed in a stereotaxic apparatus. The skull was exposed, and a small hole was drilled to expose the dura on one side; this was removed, and the probe was inserted vertically at the level of the shell or of the core of the NAc or of the PFCX according to the atlas of Paxinos and Watson (1998) (coordinates shell: anterior, 2.2; lateral, 1 from bregma; ventral, -7.8 from dura; core: anterior, 1.4; lateral, 1.9 from bregma; ventral, -7.8 from dura; PFCX: anterior, 3.7; lateral, 0.8 from bregma; ventral, -5 from dura). In the same session, an oral catheter was inserted at the level of the first molar, then the PE tubing passed along the skull and was fixed to the skull with glasionomeric cement (CX-Plus; Shofu Inc., Tokyo, Japan).

On the day after surgery, the probes were connected to an infusion pump and perfused with two kind of Ringer's solutions (in mM: 147 $\mathrm{NaCl}, 4 \mathrm{KCl}$, and 2.2 or $1.2 \mathrm{CaCl}_{2}$ ) at a constant rate of $1 \mu \mathrm{l} / \mathrm{min}$. Dialysate samples $(10 \mu \mathrm{l})$ were taken every $10 \mathrm{~min}$ and injected without purification into an HPLC equipped with a reverse-phase column (LC-18 $\mathrm{DB} ; 15 \mathrm{~cm}, 5 \mu \mathrm{m}$ particle size; Supelco, Bellefonte, PA) and a coulometric detector (ESA; Coulochem II, Bedford, MA) to quantify DA. The first electrode of the detector was set at $+130 \mathrm{mV}$ (oxidation) and the second at $-175 \mathrm{mV}$ (reduction).

The composition of the mobile phase was: $50 \mathrm{~mm} \mathrm{NaH}{ }_{2} \mathrm{PO}_{4}, 0.1 \mathrm{~mm}$ $\mathrm{Na}_{2}$-EDTA, $0.5 \mathrm{~mm} N$-octyl sodium sulfate, $15 \%$ (v/v) methanol, $\mathrm{pH} 5.5$. The mobile phase was pumped with a LKB 2150 pump at a flow of 1.0 $\mathrm{ml} / \mathrm{min}$. The sensitivity of the assay for DA was $5 \mathrm{fmol} / \mathrm{sample}$.

Behavioral recording. The taste reactivity test has been used as an operational estimate of the hedonic valence (positive or negative) and hedonic impact of tastes (Grill and Norgren, 1978; Berridge, 2000). The behavior of rats was recorded during the infusion of solutions trough the oral catheter. On each treatment the oral catheter was connected to an infusion pump, and the solution (water, sucrose or chocolate, and quinine or $\mathrm{NaCl}$ ) was pumped at a constant rate of $0.2 \mathrm{ml} / \mathrm{min}$, for a total amount of 1 or $2 \mathrm{ml}$, depending on the experiment. During the taste reactivity, test animals were videotaped, and three classes of affective taste reactivity patterns were scored: positive hedonic (appetitive), negative hedonic (aversive), and neutral. Positive hedonic reactions were: lateral tongue protrusions, rhythmic tongue protrusion and paw licks; aversive reactions were: gapes, chin rubs, face washing, forelimb flails, paw tread and locomotion; neutral reactions were: rhythmic mouth movements and passive drip of the solution (Grill and Norgren, 1978; Berridge and Robinson, 1998). Each lateral and rhythmic tongue protrusion, gape, chin rub, forelimb flails, and paw tread were counted as individual events and each event was assigned one point. For the other events, one point was assigned if the duration of the event was between 1 and $5 \mathrm{sec}$ and two points if the duration of the event was $>5 \mathrm{sec}$.

As behavioral responses to Fonzies, latency to eat (appetitive response) and amount of Fonzies eaten (consummatory response) were recorded.

As behavioral reactions to the smell of red fox urine, sniffing at the stick bearing the urine-soaked wad, freezing, piloerection, and defecation were recorded for $5 \mathrm{~min}$. Each event recorded was assigned a score of one if the duration of the event or events was between 1 and $5 \mathrm{sec}$ and a score of two if the duration of the event was longer than $5 \mathrm{sec}$.

Histology. At the end of the experiment, rats were transcardially perfused with $100 \mathrm{ml}$ of saline and $500 \mathrm{ml}$ of a $4 \%$ formaldehyde and $1 \%$ calcium acetate, $100 \mathrm{~mm} \mathrm{NaCl}$ solution. The probes were removed, and the brains were cut on a vibratome in serial coronal slices oriented according to the atlas of Paxinos and Watson (1998). The location of the probes was reconstructed and referred to the atlas of Paxinos and Watson (1998) (Fig. 1).

Statistics. Statistical analysis was performed by Statistica for Windows.

Depending on the experiments, data were analyzed by one-, two- or three-way ANOVA, with time as repeated measure in the case of the serial assays of dialysate DA. Pre-exposure to a taste stimulus (chocolate) did elicit clear-cut but opposite effects on the responsiveness of DA transmission in different brain areas (see Fig. 3) and post hoc test after three-way ANOVA with time, area, and taste pre-exposure as factors failed to show significant differences. Therefore, the data obtained in each area were analyzed separately by two-way ANOVA with time as repeated measure and pre-exposure as between-subjects factor.

Results from treatments showing significant overall changes were subjected to post hoc Tukey's test; values of $p<0.05$ were considered as statistically significant. Basal values were the means of three consecutive samples differing by not $>10 \%$.

\section{RESULTS}

Basal values of DA (mean femtomoles \pm SEM) in 10 min dialysate samples were as follows: under Ringer's solution containing $2.2 \mathrm{mM} \mathrm{CaCl}_{2}$ : NAc shell, $54 \pm 6(N=75)$; NAc core, $56 \pm 6$ $(N=45)$; PFCX, $15 \pm 1(N=40)$; under Ringer's solution containing $1.2 \mathrm{mM} \mathrm{CaCl}_{2}$ : NAc shell, $35 \pm 4(N=24)$; NAc core, $38 \pm 4(N=5) ; \operatorname{PFCX} 10 \pm 0.7(N=4)$. One-way ANOVA of basal DA output under Ringer's solution with $2.2 \mathrm{~mm}$ and $1.2 \mathrm{~mm}$ $\mathrm{CaCl}_{2}$ did not reveal significant difference between groups (NAc shell, $\left.F_{(1,97)}=1.75 ; p=0.19\right)$, (NAc core, $F_{(1,48)}=1.46 ; p=$ $0.23)$, (PFCX, $\left.F_{(1,42)}=0.86 ; p=0.36\right)$.

\section{Responses to intraoral water and $\mathbf{2 0} \%$ sucrose}

Figure 2 shows the taste reactivity scores to intraoral infusion of water and $20 \%$ sucrose solution in undeprived naive rats. Water induced only mild reactions, whereas $20 \%$ sucrose induced clearcut appetitive reactions. One-way ANOVA of taste reactivity scores after intraoral water and $20 \%$ sucrose revealed significant differences between groups $\left(F_{(3,18)}=55.47 ; p=0.0001\right)$. Post hoc analysis showed that $20 \%$ sucrose induced more pronounced ap- 


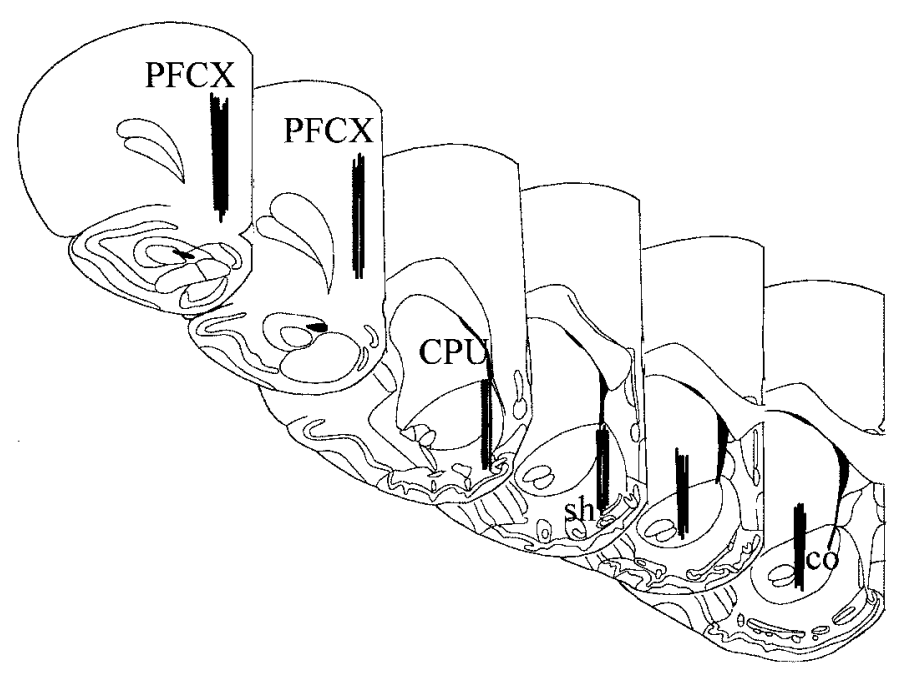

Figure 1. Localization of dialysis probes (dialysing portion) within the NAc shell and core and PFCX (according to Paxinos and Watson, 1998). $C P U$, Caudate putamen; $c o, s h$, core and shell of the NAc.

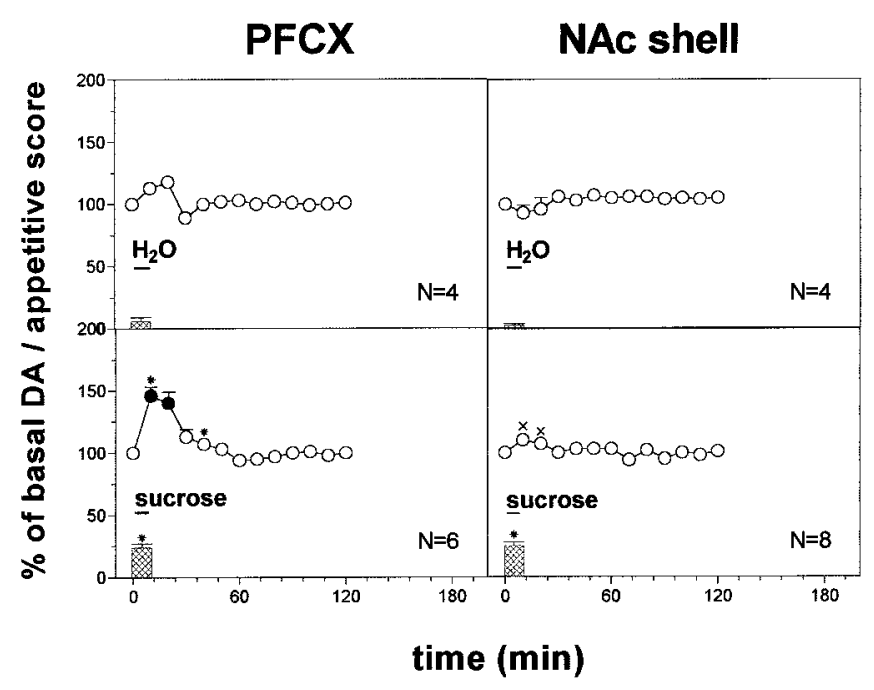

Figure 2. DA responsiveness in the PFCX and in the NAc shell to water $(1 \mathrm{ml})$ and $20 \%$ sucrose solution $(1 \mathrm{ml})$. Basal value: PFCX, $14 \pm 1$; NAc shell, $52 \pm 4$ (means \pm SEM in femtomoles per sample). Scores of behavioral reactions are also indicated. Results are means \pm SEM of the results obtained in at least four rats. $p<0.05$ with respect to basal values; * $p<0.05$ with respect to the $\mathrm{H}_{2} \mathrm{O}$ groups; $\times p<0.05$ with respect to PFCX sucrose group.

petitive reactions than water. No significant differences were observed between rats implanted in the PFCX and in the NAc shell.

Figure 2 shows the effect of the intraoral infusion of water (1 $\mathrm{ml}$ ) and of $20 \%$ sucrose solution $(1 \mathrm{ml})$ on dialysate DA in the PFCX and in the NAc shell. Two-way ANOVA of the changes of dialysate DA showed a significant effect of taste $\left(F_{(3,18)}=18.83\right.$; $p=0.0001)$ and a significant taste $\times$ time interaction $\left(F_{(9,54)}=\right.$ 8.17; $p=0.0001)$. Post hoc analysis showed that water did not affect dialysate DA in any area, while sucrose increased it only in the PFCX and to a larger extent than water.

\section{Responses to intraoral chocolate in naive and chocolate pre-exposed rats}

Figure 3 shows the score of taste reactions during intraoral chocolate $(1 \mathrm{ml})$ infusion in naive and pre-exposed to intraoral

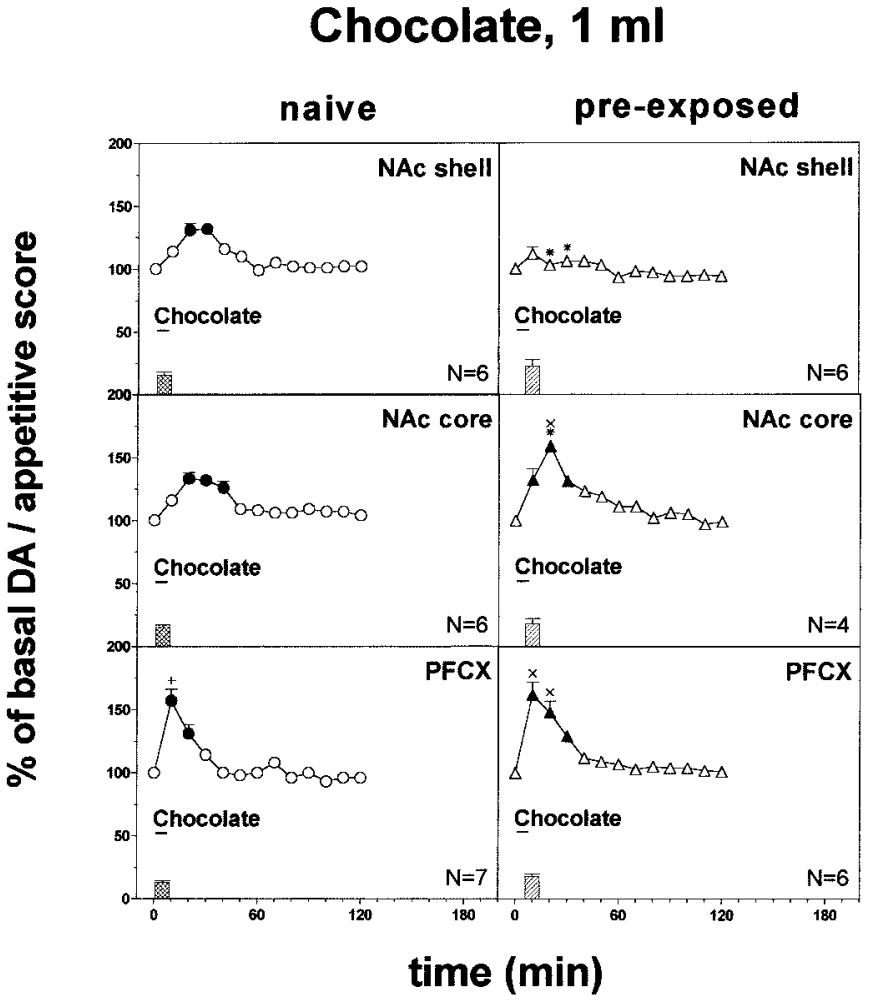

Figure 3. Effect of pre-exposure to chocolate $(1 \mathrm{ml}) 24 \mathrm{hr}$ before on DA transmission in the NAc shell and core and in the PFCX (Ringer's solution with $2.2 \mathrm{mM} \mathrm{CaCl}_{2}$ ). Basal value: NAc shell, $56 \pm 5$; NAc core, $58 \pm 6$; PFCX, $13 \pm 1$ (means \pm SEM in femtomoles per sample). Scores of ingestive reactions are also indicated. Results are means \pm SEM of the results obtained in at least four rats. $\boldsymbol{\bullet}, \boldsymbol{\Delta} p<0.05$ with respect to basal values; ${ }^{*} p<0.05$ with respect to naive group; $\times p<0.05$ with respect to pre-exposed rats implanted in the shell; $+p<0.05$ with respect to the naive group implanted in the shell and in the core.

chocolate $24 \mathrm{hr}$ before rats. Intraoral chocolate elicited only positive hedonic (ingestive) reactions. One-way ANOVA did not reveal differences between rats implanted in the different areas $\left(F_{(2,32)}=1.74 ; p=0.19\right)$ nor between naive and chocolate pre-exposed rats $\left(F_{(1,33)}=4.65 ; p=0.06\right)$.

Figure 3 shows the effect of intraoral chocolate $(1 \mathrm{ml})$ on dialysate DA in the NAc shell, NAc core, and PFCX in naive and chocolate pre-exposed rats.

Three-way ANOVA of the results obtained in the different brain areas of naive and pre-exposed rats showed a significant effect of brain area $\left(F_{(2,29)}=18.08 ; p=0.0001\right)$, a significant area $\times$ pre-exposure interaction $\left(F_{(2,29)}=14.7 ; p=0.0001\right)$, and a significant area $\times$ pre-exposure $\times$ time interaction $\left(F_{(10,145)}=\right.$ $3.72 ; p=0.0002)$. Post hoc analysis showed that chocolate increased basal dialysate DA in all three areas of naive rats, peaking on the second sample in the NAc shell and core and on the first sample in the PFCX. This effect was more pronounced in the PFCX as compared with the NAc shell and core. Post hoc test also showed that $24 \mathrm{hr}$ after a single pre-exposure, intraoral chocolate increased basal dialysate DA in the PFCX and in the NAc core but not in the NAc shell. In spite of the significant interaction between time, area, and pre-exposure on three-way ANOVA (see above), post hoc test did not reveal differences between naive and pre-exposed rats. Therefore, the results were analyzed separately for each area by two-way ANOVA with pre-exposure and time as main effects. Pre-exposure to chocolate exerted a significant effect 


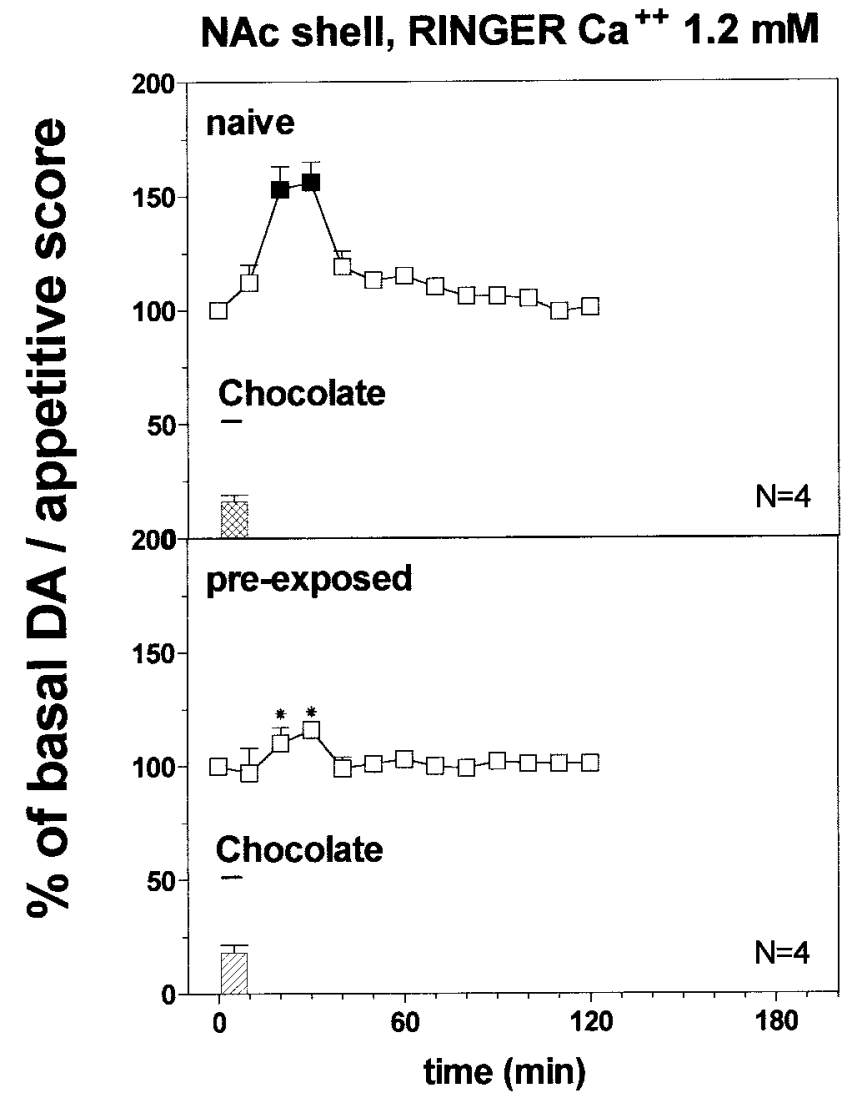

Figure 4. Effect of pre-exposure to chocolate $(1 \mathrm{ml}) 24 \mathrm{hr}$ before on DA transmission in the NAc shell (Ringer's solution with $1.2 \mathrm{mM} \mathrm{CaCl}_{2}$ ). Basal value: NAc shell, $33 \pm 3$ (means \pm SEM in femtomoles per sample). Scores of ingestive reactions are also indicated. Results are means \pm SEM of the results obtained in at least four rats. $\square p<0.05$ with respect to basal values; * $p<0.05$ with respect to naive group.

in all areas examined (NAc shell: $F_{(1,10)}=27.57, p=0.001$; NAc core: $F_{(1,8)}=12.93, p=0.001$; PFCX: $\left.F_{(1,11)}=7.16, p=0.02\right)$. Post hoc test revealed that although chocolate increased dialysate DA in the NAc shell of chocolate-naive as compared with chocolate pre-exposed rats, the reverse applied to the NAc core, where chocolate increased DA to a greater extent in pre-exposed as compared with naive rats. No significant differences were obtained in the effect of chocolate in the PFCX of naive and pre-exposed rats.

Figure 4 shows the score of taste reactions during intraoral chocolate $(1 \mathrm{ml})$ infusion in naive rats and in rats pre-exposed to intraoral chocolate $24 \mathrm{hr}$ before and implanted with microdialysis probes perfused with Ringer's solution containing $1.2 \mathrm{mM} \mathrm{Ca}^{2+}$. Intraoral chocolate elicited only positive (appetitive) reactions. One-way ANOVA did not reveal differences between naive and chocolate pre-exposed rats $\left(F_{(1,6)}=0.36 ; p=0.57\right)$.

Figure 4 shows the effect of intraoral chocolate $(1 \mathrm{ml})$ on dialysate DA in the NAc shell in naive and chocolate pre-exposed rats implanted with probes perfused with Ringer's solution containing $1.2 \mathrm{mM} \mathrm{Ca}^{2+}$. Two-way ANOVA showed a significant effect of pre-exposure $\left(F_{(1,6)}=2089.28 ; p=0.0001\right)$ and a significant pre-exposure $\times$ time interaction $\left(F_{(1,33)}=12.39 ; p=\right.$ $0.0001)$. Post hoc test revealed that chocolate increased dialysate DA in the NAc shell of chocolate-naive as compared with chocolate pre-exposed rats.

Two-way ANOVA of the results obtained in naive and choco-

\section{Fonzies}

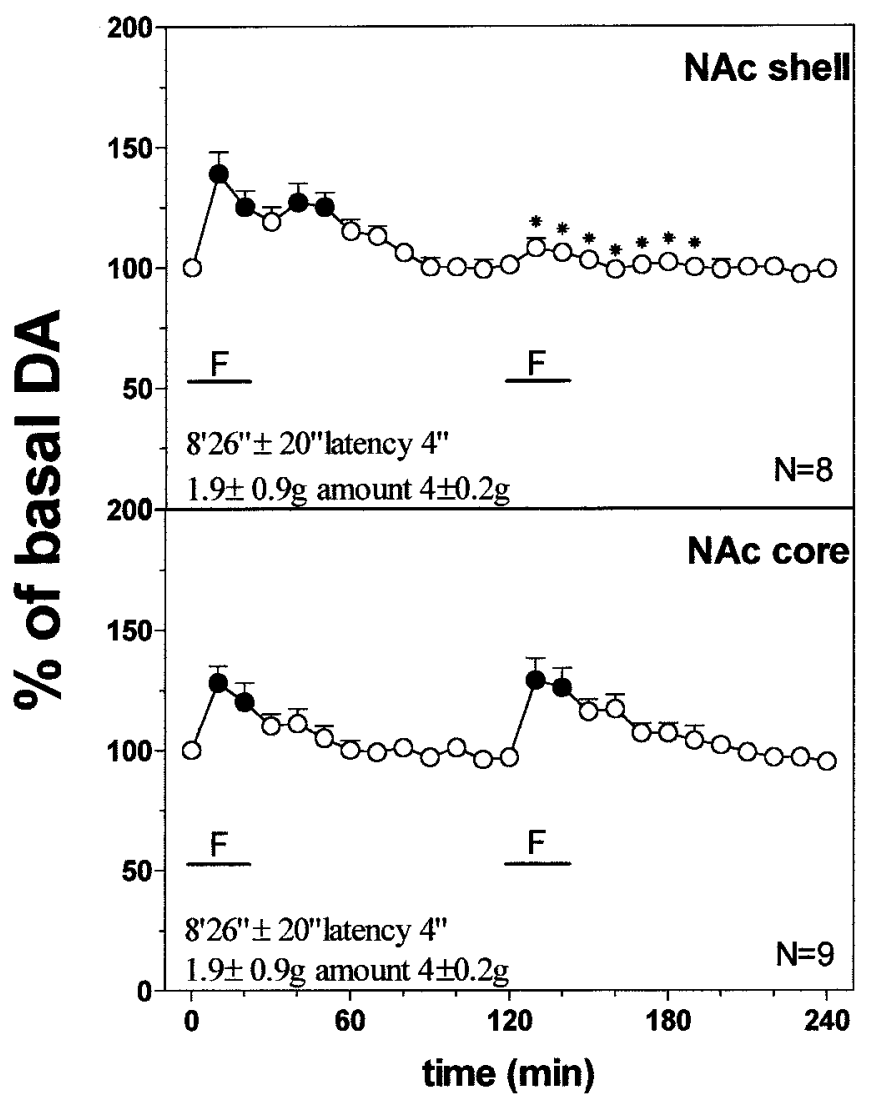

Figure 5. Effect of repeated Fonzies feeding during the same microdialysis session on DA output in the NAc shell and core. Latency to eat (in seconds) and amount of Fonzies eaten (in grams) are also indicated. Basal value: NAc shell, $54 \pm 4$; NAc core, $54 \pm 5$ (means \pm SEM in femtomoles per sample). Results are means \pm SEM of the results obtained in at least four rats. $p<0.05$ with respect to basal values; * $p<0.05$ with respect to the previous Fonzies meal.

late pre-exposed rats with probes perfused, respectively, with 2.2 and $1.2 \mathrm{mM} \mathrm{Ca}^{2+}$ showed a significant effect of group $\left(F_{(3,16)}=\right.$ $30.68 ; p=0.0001)$ and a significant group $\times$ time interaction $\left(F_{(9,48)}=14.70 ; p=0.0001\right)$. Post hoc test revealed that dialysate $\mathrm{DA}$ increased to a larger extent in naive rats perfused with 1.2 $\mathrm{mM} \mathrm{Ca}^{2+}$ as compared with $2.2 \mathrm{~mm}$ Ringer's solution.

\section{Responses to Fonzies feeding in naive and Fonzies pre-exposed rats}

Fonzies naive rats started to eat Fonzies after a latency of $8 \mathrm{~min}$ and $23 \pm 35 \mathrm{sec}$ and after $20 \mathrm{~min}$ they had eaten $1.95 \pm 0.1 \mathrm{gm}$. On the second presentation of Fonzies made $2 \mathrm{hr}$ later, latency to eat dropped to $4 \mathrm{sec}$, and amount of Fonzies eaten increased to $4 \pm 0.2 \mathrm{gm}$. One-way ANOVA revealed a significant effect of Fonzies presentation on latency to eat $\left(F_{(1,30)}=1464.15 ; p=\right.$ $0.001)$ and amount of Fonzies eaten $\left(F_{(1,30)}=333.46 ; p=0.001\right)$. Post hoc analysis showed a decrease in latency to eat and an increase in amount of Fonzies eaten on the second presentation as compared with the first.

Figure 5 shows the changes in dialysate DA in the NAc shell and core during two successive Fonzies meals $2 \mathrm{hr}$ apart. Twoway ANOVA revealed a significant group $\times$ time interaction $\left(F_{(25,63)}=4.852 ; p=0.001\right)$ in the NAc shell. Post hoc analysis 


\section{Quinine $\mathrm{HCl} 1 \times 10^{-4} \mathrm{M}, 1 \mathrm{ml}$}

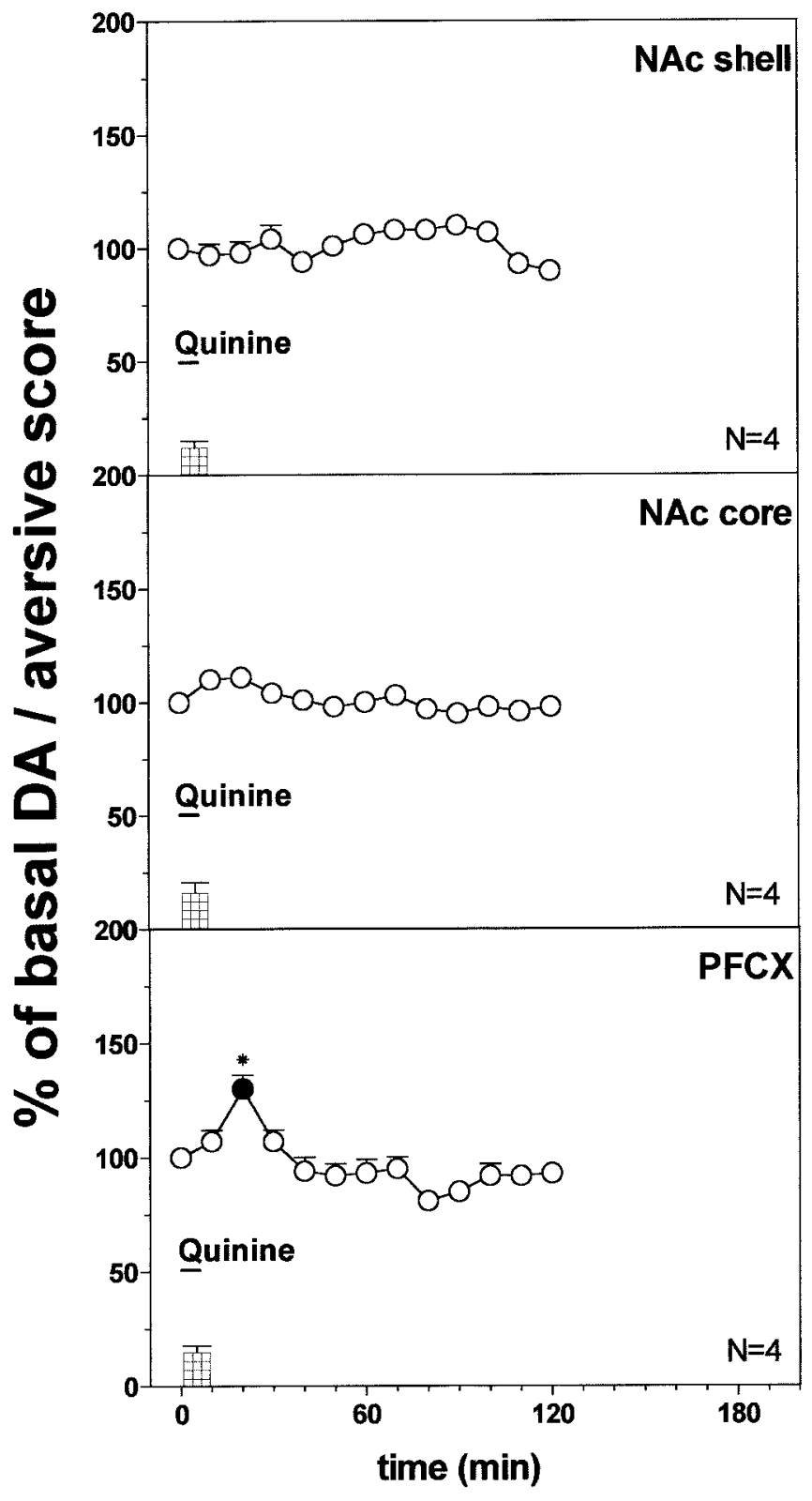

Figure 6. DA responsiveness to quinine $\mathrm{HCl} 1 \times 10^{-4} \mathrm{M}(1 \mathrm{ml})$ in the NAc shell and core and in the PFCX. Basal value: NAc shell, $54 \pm 5$; NAc core, $57 \pm 5$; PFCX, $16 \pm 1$ (means \pm SEM in femtomoles per sample). Scores of aversive reactions are also indicated. Results are means \pm SEM of the results obtained in at least four rats. $p<0.05$ with respect to basal values; ${ }^{*} p<0.05$ with respect to the group implanted in the NAc shell.

showed that DA increased over basal values in the NAc shell and core in relation to the first Fonzies meal and that after a second Fonzies meal the increase of DA was reduced in the shell but not in the core when compared with the first meal.

Responses to intraoral $1 \times 10^{-4} \mathrm{M}$ quinine in naive rats Figure 6 shows the score of taste reactions observed during intraoral infusion of $1 \times 10^{-4} \mathrm{M}$ quinine. Only negative hedonic (aversive) reactions were observed. One-way ANOVA did not reveal differences in taste reactivity to quinine between rats implanted in the different brain areas $\left(F_{(2,10)}=0.43 ; p=0.66\right)$.

\section{Quinine $5 \times 10^{-4} \mathrm{M}, 1 \mathrm{ml}$}

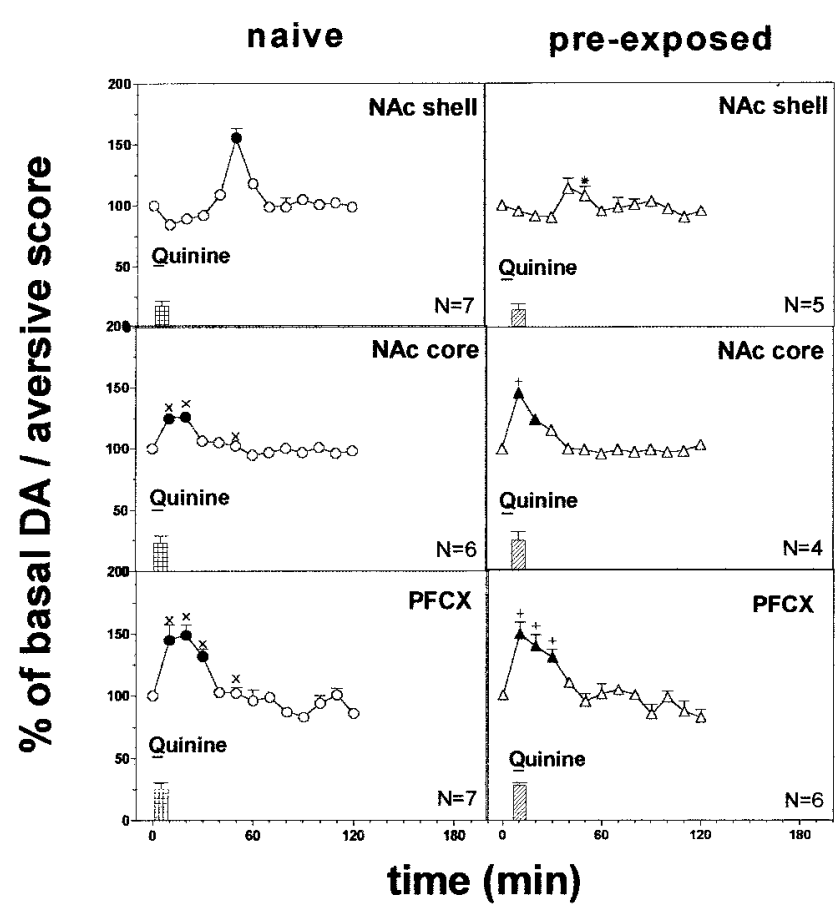

Figure 7. Effect of pre-exposure to quinine $5 \times 10^{-4} \mathrm{M}(1 \mathrm{ml}) 24 \mathrm{hr}$ before on DA transmission in the NAc shell and core and in the PFCX (Ringer's solution with $\left.2.2 \mathrm{~mm} \mathrm{CaCl}_{2}\right)$. Basal value: NAc shell, $54 \pm 5$; NAc core, $57 \pm 5$; PFCX, $16 \pm 1$ (means \pm SEM in femtomoles per sample). Scores of aversive reactions are also indicated. Results are means \pm SEM of the results obtained in at least four rats. $\boldsymbol{\bullet}, \boldsymbol{\Delta} p<0.05$ with respect to basal values; ${ }^{*} p<0.05$ with respect to the naive group; $\times p<0.05$ with respect to naive rats implanted in the NAc shell; $+p<0.05$ with respect to the pre-exposed group implanted in the NAc shell.

Figure 6 shows the effect of quinine $1 \times 10^{-4} \mathrm{M}$ infused intraorally $(1 \mathrm{ml})$ on dialysate DA in the NAc shell, core, and PFCX of quinine naive rats. Two-way ANOVA showed a significant effect of brain area $\left(F_{(2,9)}=12.13 ; p=0.003\right)$, and a significant time $\times$ area interaction $\left(F_{(8,36)}=5.7 ; p=0.0001\right)$. Post hoc test showed that $1 \times 10^{-4} \mathrm{M}$ quinine did not affect dialysate DA in the NAc shell and core but increased it in the PFCX, and this effect was significant also when compared with the NAc shell.

Responses to the intraoral infusion of $1 \mathrm{ml}$ of $5 \times 10^{-4}$ $M$ quinine in naive and quinine pre-exposed rats

Figure 7 shows the score of taste reactions observed during a 5 min infusion of $1 \mathrm{ml}$ of $5 \times 10^{-4} \mathrm{M}$ quinine in naive and quinine pre-exposed rats. Quinine induced only aversive taste reactions. Two-way ANOVA did not reveal differences in taste reactivity between naive rats and rats pre-exposed to quinine and implanted in the various areas $\left(F_{(2,29)}=0.94 ; p=0.40\right)$.

Figure 7 shows the changes in dialysate DA in the NAc shell, core, and $\mathrm{PFCX}$ of naive and quinine pre-exposed rats after intraoral infusion of $1 \mathrm{ml}$ of quinine $5 \times 10^{-4} \mathrm{M}$ during $5 \mathrm{~min}$.

Three-way ANOVA of the results obtained in the different areas of naive and pre-exposed rats revealed a significant effect of brain area $\left(F_{(2,29)}=16.15 ; p=0.0001\right)$ and a significant interaction between brain area, pre-exposure, and time $\left(F_{(12,174)}=2.45\right.$; $p=0.005)$.

Post hoc analysis showed a significant increase of basal DA in 


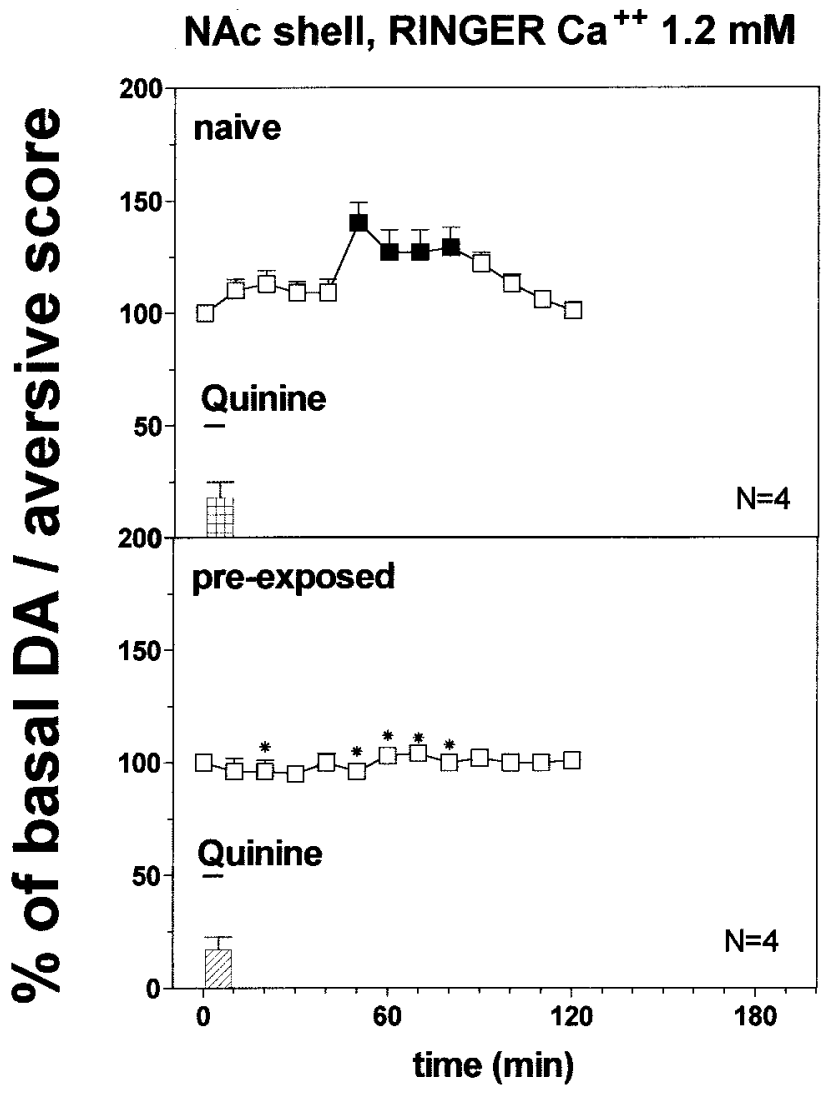

Figure 8. Effect of pre-exposure to quinine $5 \times 10^{-4} \mathrm{M}(1 \mathrm{ml}) 24 \mathrm{hr}$ before on DA transmission in the NAc shell (Ringer's solution with 1.2 $\mathrm{mM} \mathrm{CaCl}_{2}$ ). Basal value: NAc shell, $37 \pm 4$ (means \pm SEM in femtomoles per sample). Scores of aversive reactions are also indicated. Results are means \pm SEM of the results obtained in at least four rats. $p<0.05$ with respect to basal values; * $p<0.05$ with respect to the naive group.

naive rats after $5 \times 10^{-4} \mathrm{M}$ quinine in all three areas, peaking on the first sample in the PFCX and in the NAc core and only in the fifth sample in the NAc shell. Post hoc analysis also showed that the delayed increase of dialysate DA induced by quinine in the NAc shell was abolished in rats pre-exposed to quinine, and this difference was significant. No significant differences were obtained in the NAc core and in the PFCX.

Figure 8 shows the score of taste reactions observed during inf usion of $5 \times 10^{-4} \mathrm{M}$ quinine in undeprived rats implanted with probes perfused with Ringer's solution containing $1.2 \mathrm{mM} \mathrm{Ca}^{2+}$. Quinine induced only aversive taste reactions. Two-way ANOVA did not reveal differences in taste reactivity in naive rats and in rats pre-exposed to quinine $24 \mathrm{hr}$ before $\left(F_{(1,6)}=0.006 ; p=0.94\right)$.

Figure 8 shows the changes in dialysate DA in the NAc shell of naive and quinine pre-exposed rats after intraoral infusion of quinine $5 \times 10^{-4} \mathrm{M}$ in rats implanted with probes perfused with Ringer's solution containing $1.2 \mathrm{mM} \mathrm{Ca}^{2+}$.

Two-way ANOVA of the results obtained in naive and preexposed rats revealed a significant effect of pre-exposure $\left(F_{(1,6)}=\right.$ 164.7; $p=0.0001)$ and a significant pre-exposure $\times$ time interaction $\left(F_{(9,54)}=19.8 ; p=0.0001\right)$.

Post hoc analysis showed a delayed increase of basal DA in naive rats after $5 \times 10^{-4} \mathrm{M}$ quinine peaking on the fifth sample. Post hoc analysis also showed that the delayed increase of dialysate DA induced by quinine was reduced in rats pre-exposed to quinine.
Two-way ANOVA of the results obtained in naive and quinine $5 \times 10^{-4} \mathrm{M}$ pre-exposed rats with probes perfused with Ringer's solution containing 2.2 and $1.2 \mathrm{mM} \mathrm{Ca}^{2+}$ showed a significant effect of group $\left(F_{(3,16)}=16.09 ; p=0.0001\right)$ and a significant group $\times$ time interaction $\left(F_{(24,128)}=7.27 ; p=0.0001\right)$. Post hoc test revealed that in the naive groups the increase of dialysate DA was more prolonged under perfusion with Ringer's solution containing $1.2 \mathrm{mM} \mathrm{Ca}^{2+}$ as compared with perfusion with Ringer's solution containing $2.2 \mathrm{~mm} \mathrm{Ca}^{2+}$.

\section{Responses to intraoral $5 \times 10^{-4} \mathrm{M}$ quinine $(2 \times 1 \mathrm{ml}$ infusions, $20 \mathrm{~min}$ apart)}

Figure 9 shows the score of aversive reactions during each of two $5 \times 10^{-4} \mathrm{M}$ quinine infusions. One-way ANOVA did not reveal differences between groups $\left(F_{(1,12)}=1.88 ; p=0.20\right)$.

Figure 9 shows the effect of the two infusions of quinine on dialysate DA in the NAc shell. Two-way ANOVA with respect to naive group infused with $1 \mathrm{ml}$ of quinine $5 \times 10^{-4} \mathrm{M}$, showed a significant effect of group $\left(F_{(1,12)}=15.55 ; p=0.002\right)$ and a significant time $\times$ group interaction $\left(F_{(6,72)}=17.96 ; p=0.0001\right)$. Post hoc analysis revealed that the first infusion of quinine decreased dialysate DA while the second prevented the delayed increase of extracellular DA in the NAc shell induced by the first exposure.

\section{Responses to intraoral $5 \times 10^{-4} \mathrm{~m}(2 \mathrm{ml})$ quinine}

Figure 10 shows the aversive taste reactivity scores during intraoral infusion of $2 \mathrm{ml}$ of quinine $5 \times 10^{-4} \mathrm{M}$ in two groups of naive rats implanted with dialysis probes in the NAc shell and in the core, respectively. One-way ANOVA did not reveal differences between groups $\left(F_{(1,10)}=0.18 ; p=0.67\right)$.

Figure 10 shows the effect of the oral infusion of $2 \mathrm{ml}$ of quinine $5 \times 10^{-4} \mathrm{M}$ on dialysate DA in the NAc shell and in the NAc core. Two-way ANOVA revealed a significant effect of brain area $\left(F_{(1,10)}=107.3 ; p=0.0001\right)$ and a significant brain area $\times$ time interaction $\left(F_{(12,120)}=4.00 ; p=0.0001\right)$. Post hoc analysis showed a significant increase of dialysate DA in the NAc core, and this effect was significant also when compared with that in the shell. Infusion of quinine $5 \times 10^{-4} \mathrm{M}$ for $10 \mathrm{~min}(2 \mathrm{ml})$ did not affect DA in the NAc shell, and in contrast to the 5 min infusion $(1 \mathrm{ml})$, failed to increase DA in this area; infusion of $2 \mathrm{ml}$ of quinine $5 \times 10^{-4} \mathrm{M}$, instead, elicited a prolonged increase of DA in the NAc core.

\section{Responses to intraoral $0.3 \mathrm{M}$ saturated $\mathrm{NaCl}$ solutions ( $1 \mathrm{ml})$}

Figure 11 shows the taste reactivity scores during intraoral infusion of $0.3 \mathrm{M}$ and saturated $\mathrm{NaCl}$ solutions. One-way ANOVA of ingestive reactions revealed differences between groups $\left(F_{(1,6)}=\right.$ $17.18 ; p=0.006)$. One-way ANOVA of aversive reactions revealed differences between groups $\left(F_{(1,6)}=358.3 ; p=0.0001\right)$.

Figure 11 shows the time course of dialysate DA in the NAc shell during oral infusion of $1 \mathrm{ml}$ of $\mathrm{NaCl} 0.3 \mathrm{M}$ and of a saturated solution in naive rats. Two-way ANOVA showed a significant $\mathrm{NaCl}$ concentration $\times$ time interaction $\left(F_{(6,36)}=4.968 ; p=\right.$ 0.008). Post hoc analysis showed that intraoral $\mathrm{NaCl} 0.3 \mathrm{M}$ failed to affect DA transmission in the NAc shell, and saturated $\mathrm{NaCl}$ produced a delayed increase of DA over basal on the fourth and fifth sample.

Responses to intraoral $\mathrm{NaCl}$ saturated solutions ( $2 \mathrm{ml}$ ) Figure 12 shows the aversive score during intraoral infusion of 2 $\mathrm{ml}$ of saturated $\mathrm{NaCl}$ solution in two groups of naive rats im- 


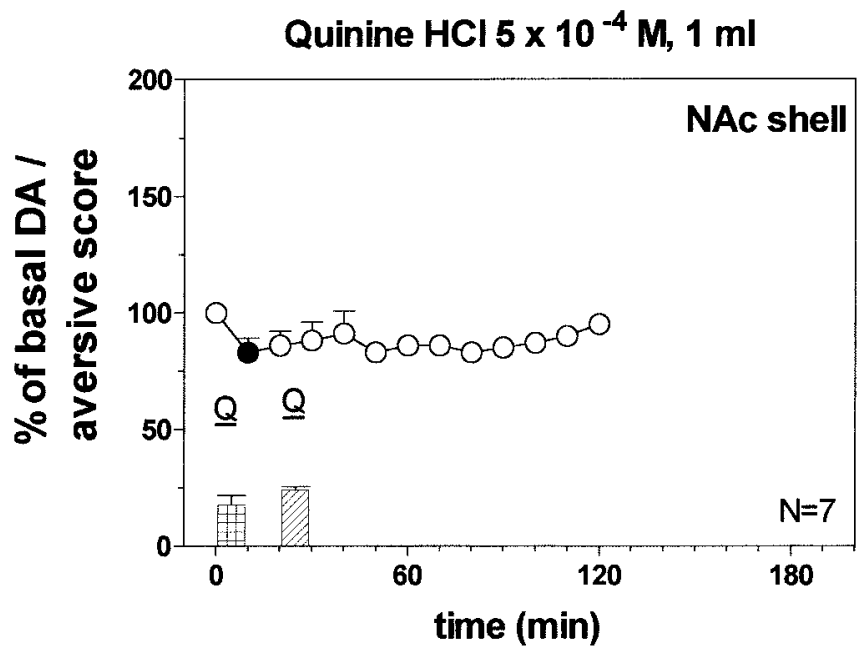

Figure 9. Effect of infusion of quinine $\mathrm{HCl} 5 \times 10^{-4} \mathrm{M}(1 \mathrm{ml})$ on DA transmission in the NAc shell of pre-exposed rats $20 \mathrm{~min}$ before. Basal value: NAc shell, $52 \pm 5$ (means \pm SEM in femtomoles per sample). Scores of aversive reactions are also indicated. Results are means \pm SEM of the results obtained in at least four rats. $0<0.05$ with respect to basal values.

planted in the NAc shell and core, respectively. One-way ANOVA did not reveal differences between groups $\left(F_{(1,10)}=\right.$ $0.005 ; p=0.95)$.

Figure 12 also shows the effect of oral infusion of $2 \mathrm{ml}$ of saturated $\mathrm{NaCl}$ solution on dialysate DA in the NAc shell and core. Two-way ANOVA showed a significant effect of brain area $\left(F_{(1,10)}=27.07 ; p=0.0004\right)$ and a significant brain area $\times$ time interaction $\left(F_{(7,70)}=2.31 ; p=0.035\right)$. Post hoc analysis revealed that inf usion of saturated $\mathrm{NaCl}$ solution, in contrast to the $5 \mathrm{~min}$ infusion $(1 \mathrm{ml})$, failed to increase DA in the NAc shell but increased it in the NAc core, and this effect was significant also in respect to the NAc shell.

\section{Responses to an aversive olfactory cue: red fox urine}

Figure 13 shows the behavioral reactions of the animals implanted in the NAc shell and core and in the PFCX after presentation of predator odor. One-way ANOVA did not revealed significant differences between rats implanted in different brain areas $\left(F_{(2,10)}=0.86 ; p=0.45\right)$.

Figure 13 shows the effect of predator odor (red fox urine) that was studied on dialysate DA from NAc shell, NAc core, and PFCX using a Ringer's solution with $1.2 \mathrm{~mm} \mathrm{CaCl}_{2}$. Two-way ANOVA of the results obtained in the different areas revealed a significant effect of brain area $\left(F_{(2,10)}=46.3 ; p=0.0001\right)$ and a significant interaction between brain area and time $\left(F_{(12,60)}=\right.$ 26.97; $p=0.0001)$.

Post hoc analysis showed a significant increase of basal DA after predator odor in the PFCX and in the NAc shell, peaking on the first sample in the PFCX and on the fourth and fifth samples in the NAc shell, but did not reveal an increase in extracellular DA from NAc core.

\section{Responses to red fox urine (two presentations $\times 5$ $\min , 20$ min apart)}

Figure 14 shows the behavioral reactions of the animals implanted in the NAc shell after each of two exposures to the predator odor. One-way ANOVA did not reveal significant differences between groups $\left(F_{(1,6)}=0.67 ; p=0.44\right)$.

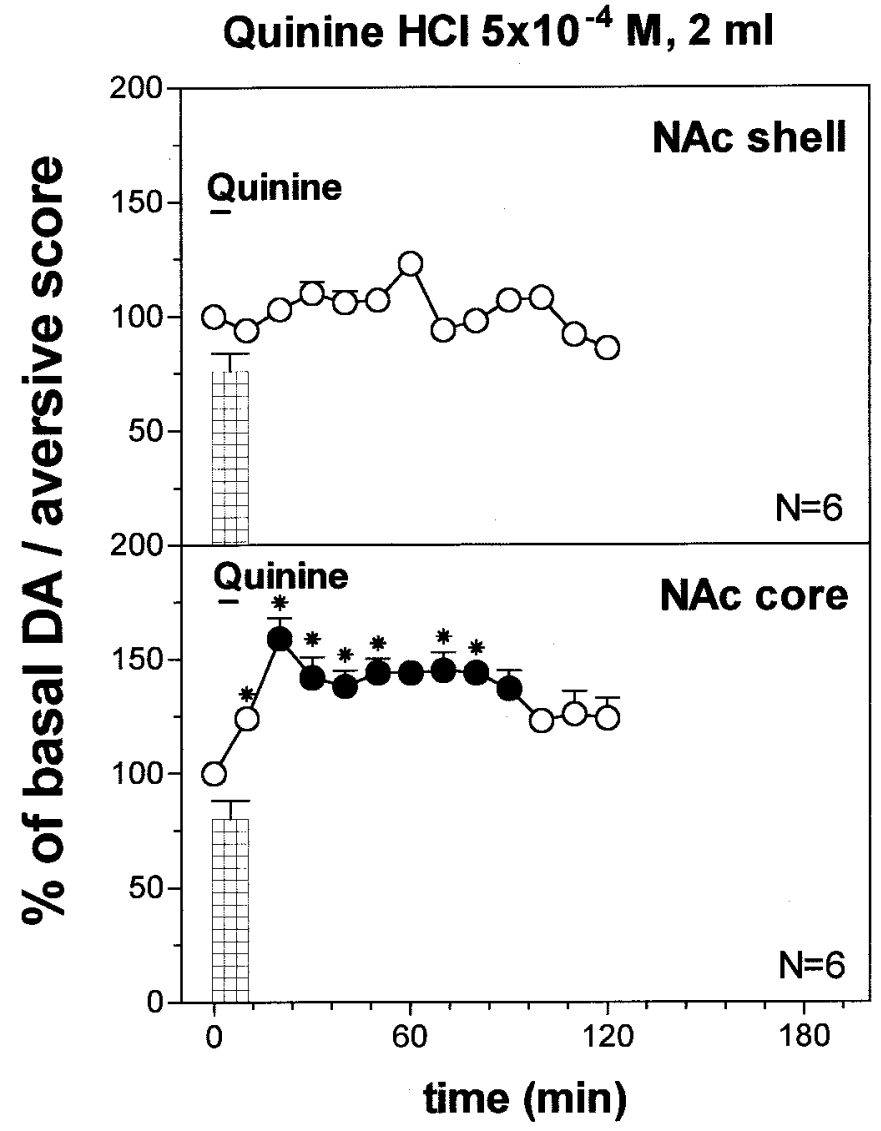

Figure 10. Effect of infusion of quinine $\mathrm{HCl} 5 \times 10^{-4} \mathrm{M}(2 \mathrm{ml})$ on DA output in the NAc shell and core. Basal value: NAc shell, $56 \pm 6$; NAc core, $58 \pm 6$ (means \pm SEM in femtomoles per sample). Scores of aversive reactions are also indicated. Results are means \pm SEM of the results obtained in at least four rats. $p<0.05$ with respect to basal values; ${ }^{*} p<0.05$ with respect to the NAc shell group.

Figure 14 shows the effect of the double exposure to the predator odor on dialysate DA in the NAc shell. Two-way ANOVA, with respect to naive group, revealed a significant effect of group $\left(F_{(1,6)}=51.09 ; p=0.0003\right)$ and a significant group $\times$ time interaction $\left(F_{(1,6)}=14.19 ; p=0.0001\right)$. Post hoc analysis revealed that the first presentation of red fox urine did not affect DA in the NAc shell and that the second exposure to the predator odor prevented the delayed increase of extracellular DA in the NAc shell induced by the first exposure.

\section{DISCUSSION}

The main finding of this study is that the response of DA transmission to motivational stimuli differs among different terminal DA areas in relation to their motivational valence (appetitiveaversive), novelty, and value. Specifically, DA responsiveness in the NAc shell is an integrated function of motivational valence and novelty, whereas in the NAc core and in the PFCX, it is an expression of generic motivational value.

Motivational stimuli increased DA in the NAc core and in the PFCX without delay and independently from their positive (appetitive) or negative (aversive) valence. In contrast, aversive and appetitive stimuli differentially affected NAc shell DA. Thus, NAc shell DA rapidly increased in response to an appetitive unfamiliar taste (sweet chocolate, Fonzies) but was unaffected 
NAc shell

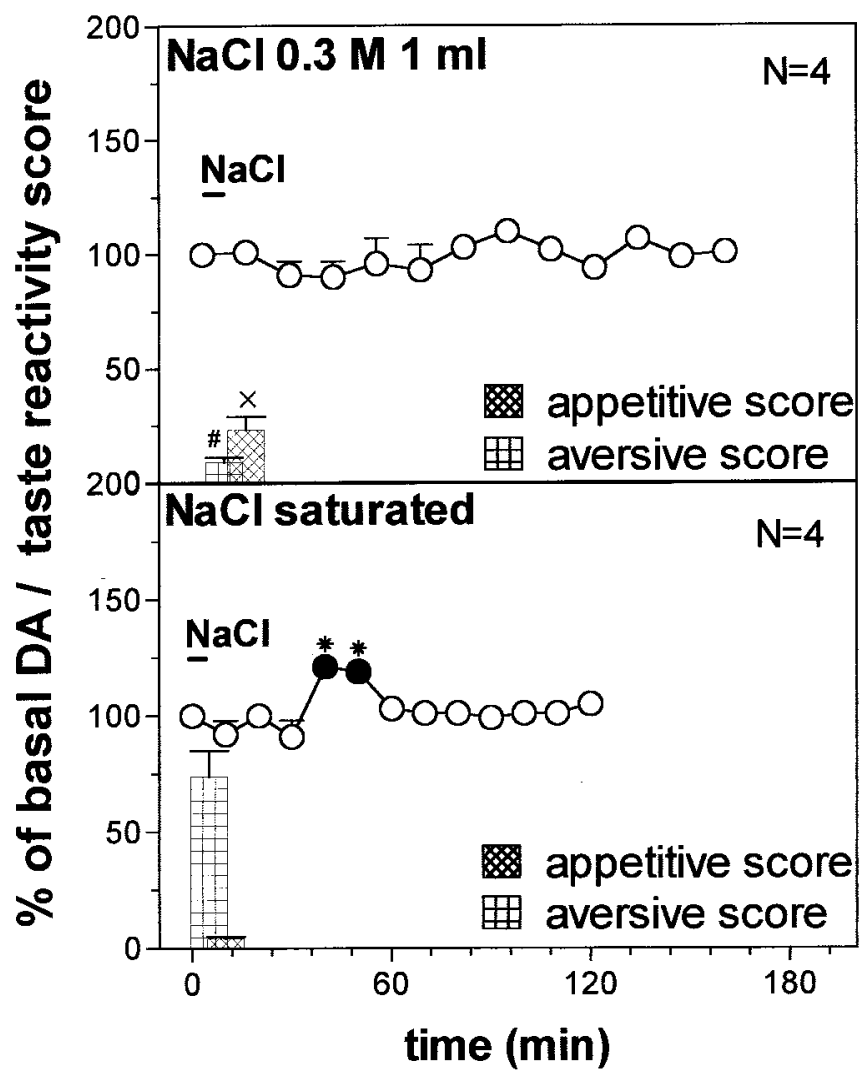

Figure 11. DA response to $0.3 \mathrm{M} \mathrm{NaCl}(1 \mathrm{ml})$ and $\mathrm{NaCl}$ saturated solution (1 ml) DA transmission in the NAc shell. Basal value: NAc shell, $54 \pm 4$ (means \pm SEM in femtomoles per sample). Score of taste reactivity is also indicated (ingestive and aversive). Results are means \pm SEM of the results obtained in at least four rats. $p<0.05$ with respect to basal values; * $p<0.05$ with respect to the $\mathrm{NaCl} 0.3$ M group; $\# p<0.05$ with respect to the aversive score of $\mathrm{NaCl}$ saturated group; $\times p<0.05$ with respect to the appetitive score of $\mathrm{NaCl}$ saturated group.

by a 10 min application of aversive tastes (quinine; saturated $\mathrm{NaCl}$ solutions). Shorter-lasting $(5 \mathrm{~min})$ application of an aversive taste or of an aversive odor (red fox urine) increased NAc shell DA in a delayed, transitory manner, and this effect was prevented by exposure to a second application of the stimulus (either quinine or red fox urine) 20 min after the first. The striking similarity of the effects of the aversive taste and of the aversive olfactory stimulus indicates the general significance of these effects. Moreover, the delayed nature of the increase of DA in the NAc shell and its prevention by a $10 \mathrm{~min}$ application or by a second application preceding the delayed increase suggests that the delayed increase of DA in the NAc shell after aversive stimuli is not directly related to their aversive nature. We hypothesize that the delayed stimulatory response of DA in the NAc shell to short-lasting aversive stimuli is appetitive in nature, being related to the positive state associated to recovery from the aversive stimulus.

Although eventually necessary, positive valence is not sufficient for stimulation of DA transmission in the NAc shell by motivational stimuli. Thus, sucrose (20\%), although no less effective as an appetitive stimulus than sweet chocolate, failed to stimulate DA in the NAc shell. Consistent with this interpretation is the observation that the stimulation of NAc shell DA by chocolate undergoes one-trial habituation, thus confirming and extending previous observations with feeding of palatable foods (Bassareo and Di Chiara, 1997, 1999b). In the rat, even a mild degree of food deprivation is sufficient to abolish habituation of DA activation in response to palatable food (Bassareo and Di Chiara, 1999b), an observation that might account for the failure of DA neurons to undergo habituation in food-restricted monkeys (Schultz et al., 1993, 1997).

Based on feeding measures (latency to eat and amount of food eaten), we previously excluded (Bassareo and Di Chiara, $1999 b)$ that habituation of DA release in the NAc shell is related to satiety-induced hedonic devaluation (Rolls et al., 1981; Rolls and Rolls, 1997). Feeding measures, however, are influenced by factors (e.g., neophobia) independent from the intrinsic hedonic value of food and therefore are not a reliable expression of such value. The present observation that habituation of the DA response is not associated to a reduction in hedonic taste reactions indicates that habituation is unrelated to hedonic devaluation.

Because novelty is a prerequisite of stimulation of DA release in the NAc shell, but not of behavioral hedonic reactions, release of DA in this area is likely to be a consequence rather than the cause of the appetitive properties of taste stimuli, consistently with the idea that taste-hedonia does not depend on DA (Berridge and Robinson, 1998). These obser-

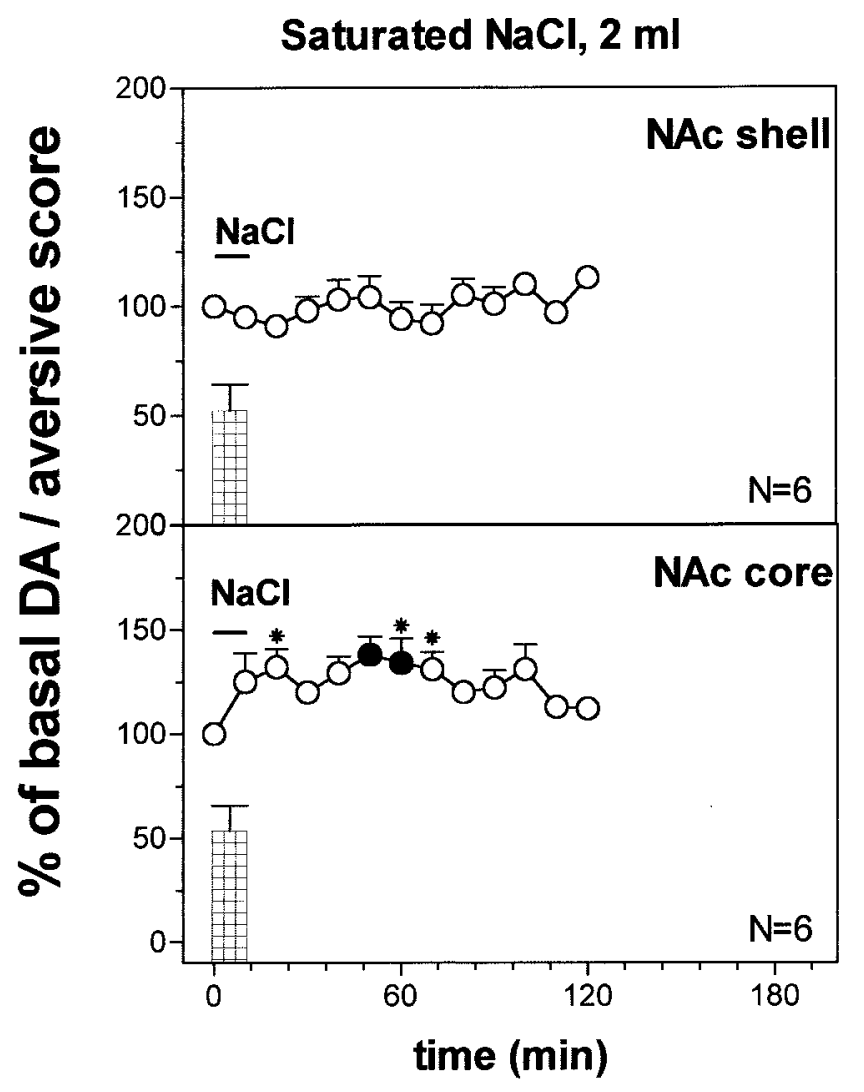

Figure 12. Effect of intraoral $\mathrm{NaCl}$ saturated solution $(2 \mathrm{ml}) \mathrm{DA}$ output in the NAc shell and in the core. Basal value: NAc shell, $52 \pm 5$; NAc core, $56 \pm 5$ (means \pm SEM in femtomoles per sample). Scores of aversive reactions are also indicated. Results are means \pm SEM of the results obtained in at least four rats. $p<0.05$ with respect to basal values; ${ }^{*} p<$ 0.05 with respect to the NAc shell group. 


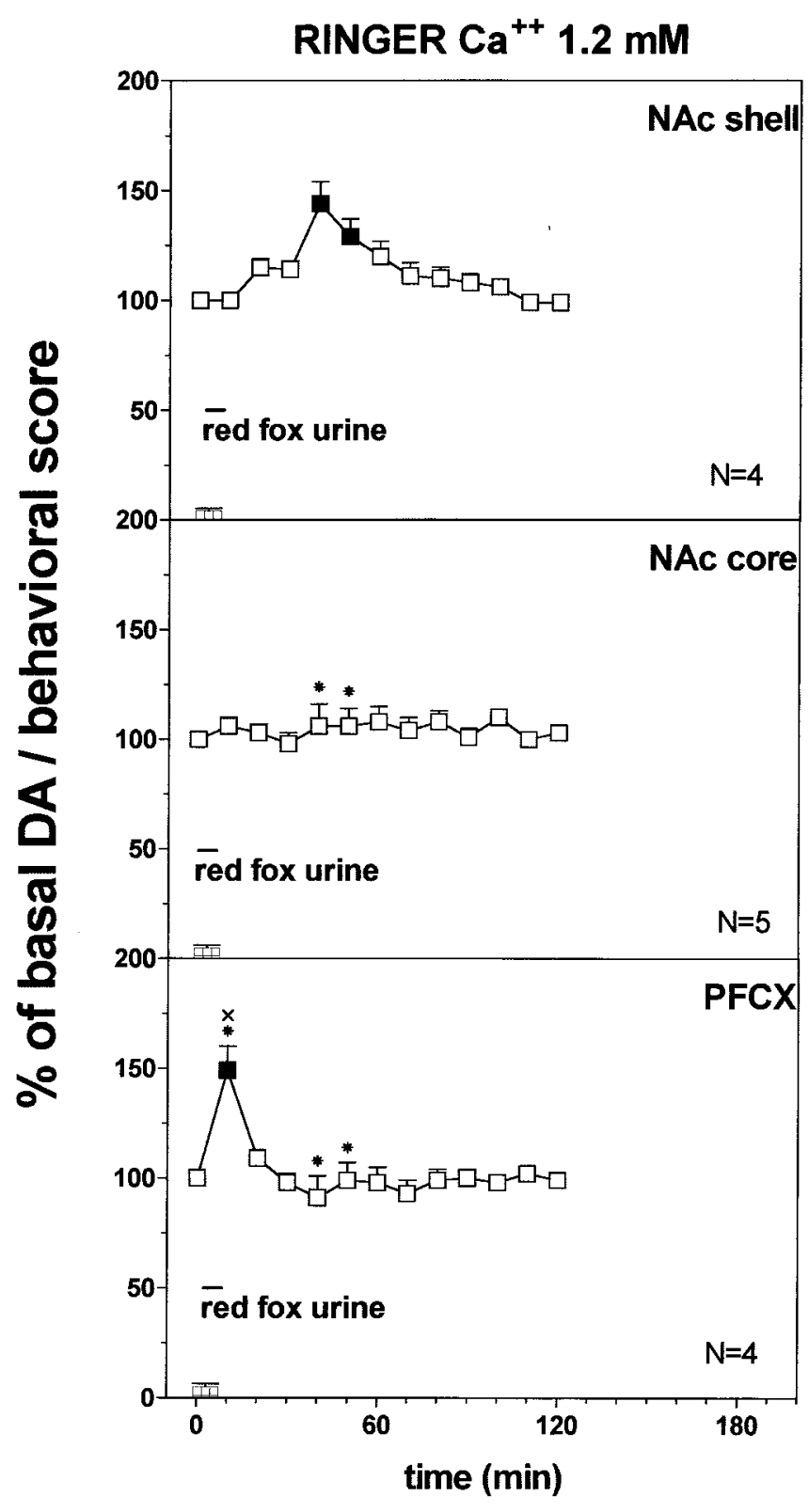

Figure 13. Effect of predator odor (red fox urine) on DA transmission in the NAc shell (Ringer's solution with $1.2 \mathrm{mM} \mathrm{CaCl}_{2}$ ). Basal value: NAc shell, $35 \pm 4$; NAc core, $38 \pm 4$; PFCX, $10 \pm 1$ (means \pm SEM in femtomoles per sample). Scores of aversive reactions are also indicated. Results are means \pm SEM of the results obtained in at least four rats. 口 $p<0.05$ with respect to basal values; ${ }^{*} p<0.05$ with respect to NAc shell group; $\times p<0.05$ with respect to NAc core group.

vations, however, leave open the issue of a role of DA in state-hedonia (euphoria, eutimia) as distinct from stimulusbound (e.g., taste) hedonia (Wise et al., 1978; Wise, 1982; Drevets et al., 2001).

In the NAc shell, one-trial habituation was also observed to the delayed stimulatory response to short-lasting application of aversive tastes, an observation consistent with a secondary appetitive nature of this response. No single-trial habituation was observed to the stimulatory response of DA to appetitive and aversive stimuli in the PFCX and in the NAc core, suggesting that novelty is not a prerequisite of the responsiveness of DA in these areas.
Thus, PFCX and NAc core DA, in contrast to NAc shell DA, does not appear to code for motivational valence nor for novelty but for generic motivational value.

The complexity of the changes in DA responsiveness was not the result of the use of $2.2 \mathrm{~mm} \mathrm{Ca}^{2+}$ in the Ringer's solution as perfusion with $1.2 \mathrm{mM} \mathrm{Ca}^{2+}$ not only reproduced the adaptive changes induced by pre-exposure to chocolate and quinine in the NAc shell, but its effects were even more pronounced than after $2.2 \mathrm{~mm} \mathrm{Ca}^{2+}$. On the other hand, no significant differences were observed in the basal concentrations of DA in the NAc shell and core and in the PFCX after perfusion with 1.2 $\mathrm{mM}$ and $2.2 \mathrm{mM} \mathrm{Ca}^{2+}$. Finally, the effects of the aversive odor (red fox urine) were obtained after perfusion with $1.2 \mathrm{~mm}$ $\mathrm{Ca}^{2+}$ and were qualitatively similar to those observed with quinine.

Collectively, the present observations contradict the widely held belief that DA transmission is activated by motivational stimuli in a uniform manner across different terminal DA areas in relation to their motivational value (motivational salience) (Salamone, 1994; Berridge and Robinson, 1998; Horvitz, 2000). This notion, although appropriate for the NAc core and PFCX, does not apply to the NAc shell where the responsiveness of DA transmission is critically dependent on specific properties of the stimulus, namely its novelty and motivational valence.

The present observations might account for some discrepancies of the literature over the response of NAc DA to aversive stimuli. Various studies have reported increases in DA function or in DA release after exposure to aversive stimuli (for review, see Horvitz, 2000). Our results in the NAc core and PFCX confirm these observations. As to the NAc shell, the observed increases have been obtained under experimental procedures or conditions such as postmortem estimation of DOPAC-DA ratio (Deutch and Cameron, 1992), long sampling interval in microdialysis studies ( $\geq 20 \mathrm{~min}$ ), or longlasting (10-20 min) exposures to the aversive stimulus (Kalivas and Duffy, 1995) that do not allow a precise estimation of the time relationship between the changes in DA function and the

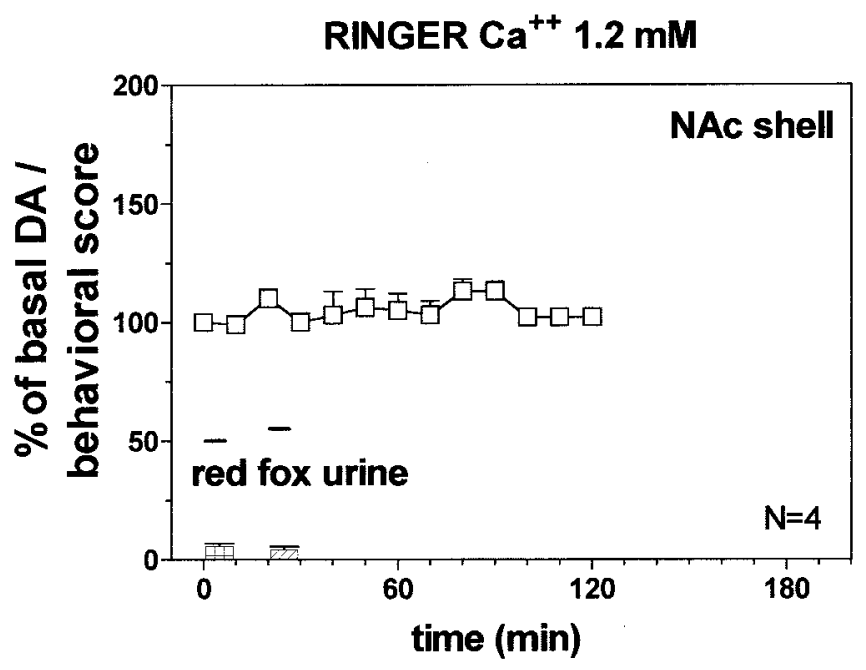

Figure 14. Effect of predator odor (red fox urine) on DA transmission in the NAc shell of pre-exposed rats 20 min before (Ringer's solution with $1.2 \mathrm{mM} \mathrm{CaCl}_{2}$ ). Basal value: NAc shell, $35 \pm 3$ (means $\pm \mathrm{SEM}$ in femtomoles per sample). Scores of aversive reactions are also indicated. Results are means \pm SEM of the results obtained in at least four rats. 
aversive properties of the stimulus. Under appropriate conditions, the increase of NAc shell DA by aversive stimuli does not appear directly related to the aversive stimulus. We speculate that this effect is the expression of the positive state resulting from termination of the aversive stimulus after short lasting exposures; longer exposures might result in visceral malaise exceeding the duration of the infusion and preventing full recovery and a late stimulatory response of DA in the shell.

What is than the direct effect of aversive stimuli on NAc shell DA? We have reported that short-lasting $(5 \mathrm{~min})$ tail pinch induces an immediate reduction of DA in the NAc shell (Di Chiara et al., 1999). Moreover, in a conditioned taste aversion paradigm, intraoral saccharin increases dialysate DA in the NAc before pairing with an aversive state while decreased it thereafter (Mark et al., 1991). In the present study, intraoral application of quinine $\left(5 \times 10^{-4} \mathrm{M}\right)$ for $5 \mathrm{~min}$ significantly reduced DA in the NAc shell in the first sample if the late rise of DA is abolished by a second quinine application 20 min after the first (see Results). A significant reduction of DA is also obtained on post hoc analysis after one-way ANOVA if only the first four samples of experiments reported in Figures 7 and 9 are considered $\left(F_{(3,52)}=5.649\right.$; $p=0.002)$. These observations might suggest that a phasic, short-lasting inhibition is the immediate effect of aversive stimuli on DA transmission in the NAc shell. These changes, however, do not always result in a significant change in dialysate DA because of their short-lasting nature.

The circumstance that appetitive tastes activate DA transmission in the NAc shell only if the taste is novel is consistent with the notion that taste conditioning, like Pavlovian learning in general, is most efficient if the to-be-conditioned stimulus is novel (Rescorla and Wagner, 1972). The strong dependence of DA responsiveness in the NAc shell from novelty is therefore suggestive of a role of NAc shell DA in Pavlovian learning mechanisms (Bassareo and Di Chiara, 1997, 1999a,b). Consistently with this hypothesis, SCH 39166, a D1 receptor antagonist, impairs learning of conditioned aversion to the same taste chocolate found here to release DA in the NAc shell (Fenu et al., 2001).

On the other hand, the notion that generic motivational value is the main determinant of DA responsiveness in the NAc core and PFCX is consistent with a role of these areas in the retrieval and expression of Pavlovian associations and in their transfer to instrumental action (Kelley et al., 1997; Hall et al., 2001).

\section{REFERENCES}

Abercrombie ED, Keefe KA, Di Frischia DS, Zigmond MJ (1989) Differential effect of stress on in vivo dopamine release in the striatum, nucleus accumbens and medial frontal cortex. J Neurochem 52:1655-1658.

Bassareo V, Di Chiara G (1997) Differential influence of associative and nonassociative learning mechanisms on the responsiveness of prefrontal and accumbal dopamine transmission to food stimuli in rats fed ad libitum. J Neurosci 17:851-861.

Bassareo V, Di Chiara G (1999a) Differential responsiveness of DA transmission to food-stimuli in nucleus accumbens shell/core compartment. Neuroscience 89:637-641.

Bassareo V, Di Chiara G (1999b) Modulation of feeding-induced activation of mesolimbic dopamine transmission by appetitive stimuli and its relation to motivational state. Eur J Neurosci 11:4389-4397.

Bassareo V, Tanda G, Petromilli P, Giua C, Di Chiara G (1996) Nonpsychostimulant drugs of abuse and anxiogenic drugs activate with differential selectivity dopamine transmission in the nucleus accumbens and in the medial prefrontal cortex of the rat. Psychopharmacology 124:293-299.

Berridge KC (2000) Measuring hedonic impact in animals and infants: microstructure of affective taste reactivity patterns. Neurosci Biobehav Rev 24:173-198.

Berridge KC, Robinson TE (1998) What is the role of dopamine in reward: hedonic impact, reward learning, or incentive salience? Brain Res Rev 28:309-369.

Deutch AY, Cameron DS (1992) Pharmacological characterization of dopamine systems in the nucleus accumbens core and shell. Neuroscience 46:49-57.

Di Chiara G (1995) The role of dopamine in drug abuse viewed from the perspective of its role in motivation. Drug Alcohol Depend 38:95-137.

Di Chiara G, Tanda G, Frau R, Carboni E (1993) On the preferential release of dopamine in the nucleus accumbens by amphetamine: further evidence obtained by vertically implanted concentric dialysis probes. Psychopharmacology 112:98-402.

Di Chiara G, Tanda G, Carboni E (1996) Estimation of in vivo neurotransmitters release by brain microdialysis: the issue of validity. Behav Pharmacol 7:640-657.

Di Chiara G, Loddo P, Tanda G (1999) Reciprocal changes in prefrontal and limbic dopamine responsiveness to aversive and rewarding stimuli after chronic mild stress: implications for the psychobiology of depression. Biol Psychiatry 46:1624-1633.

Drevets WC, Gautier C, Price JC, Kupfer DJ, Kinahan PE, Grace AA, Price JL, Mathis CA (2001) Amphetamine induced dopamine release in human ventral striatum correlates with euphoria. Biol Psychiatry 49:81-96.

Fenu S, Bassareo V, Di Chiara G (2001) A role for dopamine $\mathrm{D}_{1}$ receptors of the nucleus accumbens shell in conditioned taste aversion learning. J Neurosci 21:6897-6904.

Grill HJ, Norgren R (1978) The taste reactivity test. I. Mimetic responses to gustatory stimuli in neurologically normal rats. Brain Res 143:263-279.

Hall J, Parkinson JA, Connor TM, Dickinson A, Everitt BJ (2001) Involvment of central nucleus of the amygdala and nucleus accumbens core in mediating Pavlovian influences on instrumental behaviour. Eur J Neurosci 13:1984-1992.

Horvitz JC (2000) Mesolimbocortical and nigrostriatal dopamine responses to salient non-reward events. Neuroscience 96:651-656.

Horvitz JC, Stewart T, Jacobs BL (1997) Burst activity of ventral tegmental dopamine neurons is elicited by sensory stimuli in the awake cat. Brain Res 759:251-258.

Imperato A, Puglisi-Allegra S, Casolini P, Zocchi A, Angelucci L (1989) Stress-induced enhancement of dopamine and acetylcholine release in limbic structures: role of corticosterone. Eur J Pharmacol 165:337-338.

Kalivas PW, Duffy P (1995) Selective activation of dopamine transmission in the shell of the nucleus accumbens by stress. Brain Res 675:325-328.

Kelley AE, Smith-Roe SL, Holahan MR (1997) Response-reinforcement learning is dependent on $N$-methyl-D-aspartate receptor activation in the nucleus accumbens core. Proc Natl Acad Sci USA 94: 12174-12179.

Mark GP, Blander DS, Hoebel BG (1991) A conditioned stimulus decreases extracellular dopamine in the nucleus accumbens after the development of a learned taste aversion. Brain Res 551:308-310.

Mirenowicz J, Schultz W (1996) Preferential activation of midbrain dopamine neurons by appetitive rather than aversive stimuli. Nature 379:449-451.

Paxinos G, Watson C (1998) The rat brain in stereotaxic coordinates, Ed 4. New York: Academic.

Phillips AG, Pfaus JG, Blaha CD (1991) Dopamine and motivated behavior: insights provided by in vivo analysis. In: The mesolimbic dopamine system: from motivation to action (Willner P, Scheel-Krüger J, eds), pp 199-224. Chichester, UK: Wiley.

Pontieri FE, Tanda G, Di Chiara G (1995) Intravenous cocaine, morphine and amphetamine preferentially increase extracellular dopamine in the shell as compared with the core of the rat nucleus accumbens. Proc Natl Acad Sci USA 92:12304-12308.

Pontieri FE, Tanda G, Orzi F, Di Chiara G (1996) Effects of nicotine on the nucleus accumbens and similarity to those of addictive drugs. Nature 382:255-257.

Redgrave P, Prescott TJ, Gurney K (1999) Is the short-latency dopamine response too short to signal reward error? Trends Neurosci 22:146-151.

Rescorla RA, Wagner AR (1972) A theory of Pavlovian conditioning: Variations in the effectiveness of reinforcement and nonreinforcement In: Classical conditioning II: current research and theory (Black $\mathrm{AH}$, Prokasy WF, eds), pp 64-69. New York: Appleton-Century-Crofts.

Rolls BJ, Rolls ET (1997) Olfactory sensory-specific satiety in humans. Physiol Behav 62:461-473.

Rolls BJ, Rolls ET, Rowe EA, Sweeney K (1981) Sensory specific satiety in man. Physiol Behav 27:137-142.

Salamone JD (1994) The involvement of nucleus accumbens dopamine in appetitive and aversive motivation. Behav Brain Res 61:117-133.

Salamone JD (1996) The behavioral neurochemistry of motivation: methodological and conceptual issues in studies of the dynamic activity of nucleus accumbens dopamine. J Neurosci Methods 64:137-149.

Schultz W (1998) Predictive reward signal of dopamine neurons J Neurophysiol 80:1-27. 
Schultz W, Apicella P, Ljungberg T (1993) Responses of monkey dopamine neurons to reward and conditioned stimuli during successive steps of learning a delayed response task. J Neurosci 13:900-913.

Schultz W, Dayan P, Montague PR (1997) A neural substrate of prediction and reward. Science 275:1593-1599.

Tanda G, Bassareo V, Di Chiara G (1996) Mianserin markedly and selectively increases extracellular dopamine in the prefrontal cortex as compared to the nucleus accumbens of the rat. Psychopharmacology 123:127-130.

Tanda G, Pontieri FE, Di Chiara G (1997) Cannabinoid and heroin activation of mesolimbic dopamine transmission by a common $\mu_{1}$ opioid receptor mechanism. Science 276:2048-2050.
Ungersted U (1984) Measurement of neurotransmitter release by intracranial dialysis. In: Measurement of neurotransmitter release in vivo (Marsden CA, ed), pp 81-105. New York: Wiley.

Westerink BHC (1995) Brain microdialysis and its application for the study of animal behavior. Behav Brain Res 70:103-124.

Wilson C, Nomikos GC, Collu M, Fibiger HC (1995) Dopaminergic correlates of motivated behavior: importance of drive. J Neurosci 15:5169-5178.

Wise RA (1982) Neuroleptics and operant behavior: the anhedonia hypothesis. Behav Brain Sci 5:9-87.

Wise RA, Spindler J, De Witt H, Gerber GJ (1978) Neuroleptic-induced "anhedonia" in rats: pimozide blocks reward quality of food. Science 201:262-264. 